\title{
Deposit Insurance System and the Commercial Bank Loan Loss Provisions
}

\author{
Zhiyi Wang \\ School of Management, Jinan University, Guangzhou, China \\ Email: m18202759758@163.com
}

How to cite this paper: Wang, Z.Y. (2019) Deposit Insurance System and the Commercial Bank Loan Loss Provisions. Modern Economy, 10, 175-187. https://doi.org/10.4236/me.2019.101012

Received: December 17, 2018

Accepted: January 11, 2019

Published: January 14, 2019

Copyright $\odot 2019$ by author(s) and Scientific Research Publishing Inc. This work is licensed under the Creative Commons Attribution International License (CC BY 4.0).

http://creativecommons.org/licenses/by/4.0/

\begin{abstract}
The article mainly analyzes the deposit insurance system in our country promulgated after the provision for the impact of bank loan loss provisions. Empirical study found that the deposit insurance system in our country was promulgated in 2015, the bank's loan loss provisions increased, among them, the big bank loan loss provisions significantly increased. After separating the manipulated loan loss provisions, we found that the manipulated loan loss provisions increased. Further study found that, following the promulgation of the deposit insurance system, managers in commercial bank weakened the motive of income smoothing, but the bank's capital management behavior does not.
\end{abstract}

\section{Keywords}

Loan Loss Provisions, Deposit Insurance System, Income Smoothing

\section{Introduction}

Deposit insurance system is a system for protecting depositors. Most of the scholars researched the relationship between deposit insurance system and the moral risk, interest rate marketization and the aspects of bank run, and discussed the necessity and feasibility of the system in our country promulgated and enacted after the impact of the banking industry in China. Before deposit insurance system is put forward in 2015, our country has executed the implicit insurance system in our country, which is that when the bank financial crisis or loss incurs, all losses shall be borne by the government. The implicit insurance system not only increased the government's financial burden, but also produced adverse effect of the implementation of the fair competition mechanism for the banking industry, which led to the low efficiency of bank [1]. To investors, do- 
minant insurance system has a different message, namely the government no longer bears the banks' losses in full. Government only needs to take partly to the behavior of the losses and commercial banks need to take more losses, also the bank will take corresponding measures to make sure they have enough loan loss provisions to defend crises.

From previous studies, we have found that the loan loss provisions as commercial banks in the financial statements are a larger accrued items and have a greater influence on the net profit for banks, and because of its measuring scope of discretion of existence, loan loss provisions are the bank's natural tool for income smoothing [2]. At the same time, the bank will use loan loss provisions for capital management, namely when the bank capital adequacy cannot meet the regulatory requirements, managers will increase loan loss provisions to get the corresponding standard [3]. If bank loan loss provisions in deposit insurance system are promulgated after the increase, the increase will not be the same as in the past, which was due to the motive of income smoothing and capital management. If the deposit insurance system could reduce the behavior of manipulating loan loss provisions, this system would do depositors and investors a favor which could let the whole market more stable.

Contribution of this paper is mainly manifested in the following aspects: 1) from the angle of view of the deposit insurance system in our country promulgated by empirical analysis inspection system to our country bank loan provisions issued by the impact of provision, enriched the deposit insurance system and loan loss provisions research from two aspects of literature; 2) past research has shown that bank loan scale is not a factor for loan loss provisions of the contact, but this article found that in the influence of the system, the bank scale is one of the factors that affect the number of loan loss provisions; 3 ) in this paper, we analyze the motive of income smoothing and capital management after the system settled, which have a significance for strengthening our country commercial bank compliance regulation, better guarantee of the interests of the depositors and decreasing commercial banks operating risk.

The remainder of the study is organised as follows. In Section 2, we reviews some integral part of the deposit insurance system and loan loss provisions. Section 3 describes three hypotheses for this article. Section 4 presents our sample selection and empirical models. Section 5 presents the results of the main estimations. Section 6 displays the estimations with substitute variables as a robustness check. We conclude in Section 7.

\section{Literature Review}

\subsection{The Motive of Income Smoothing and Capital Management}

High leverage, high risk characteristics of commercial bank determines its surplus volatile, in order to ensure the stability of performance, to investors to conceal the real risk, commercial banks are widespread strong income smoothing motivation [2] [3]. The influence of the macro environment, the date on the 
economy, high profits, management tend to increase loan loss provisions to income smoothing, vice versa [4]. In addition, loan loss provisions may also be influenced by the microscopic factors such as operating performance of the banks themselves, in the current business performance good (bad) and is expected to decline in operating performance (up), the management will by loan loss provisions reserves (let out) "surplus" in order to income smoothing [5].

The bank's capital mainly to cover unexpected losses, the bank in order to attract investors, often in the capital is not enough, by increasing the loan loss provisions make its capital adequacy ratio meet the specific requirements [6] [7]. Changed after 1990, the U.S. banking regulation, banks can only be limited loan loss provisions (no more than $1.25 \%$ of the assets risk weighting) as a secondary capital, from primary to secondary jumps, make bank to loan loss provisions manipulation is restrained, the motivation of management, capital management is relatively less [8]. It seems that the motive of bank capital by loan loss provisions management exists, but perhaps because of a variety of regulatory and tax policies or macro environment by some degree of inhibition [9].

\subsection{The Current Research Status of Deposit Insurance System}

Early in our country has not yet issued the deposit insurance system, there is a lot of research and analysis of the deposit insurance system in our country to emphasize the necessity and feasibility of implementing [10] [11] [12]. As countries successively promulgated the deposit insurance system, scholars at home and abroad in view of the system from the impact of recessive to dominant moral hazard for banks this Angle, found that dominant bank deposit insurance can significantly reduce the excessive risk of the bank [13]. The promulgation of the deposit insurance system in China marks the transition to the dominant system by the recessive deposit system in China. Compared directly with the central bank bail-outs, deposit insurance system can reduce the central bank to regulatory uncertainty of commercial bank, also reduced the risk of moral hazard, make the internal governance of banks is high [14]. The establishment of deposit insurance system is to prevent a run on the bank of deposit of bankruptcy, the establishment of the system makes the bank to deposit interest rate and the risk of default is more sensitive to loan [15], which makes originally implicit system of the concept of "Too big to fail" may no longer apply.

In general, the deposit insurance system and loan loss provisions for these two literature in the field of comprehensive enough, basic covers both affect and economic consequences, but there is not have the combination research of these two aspects of the literature research due to the deposit insurance system in our country is not formally issued in May 2015, in the first two years scholars cannot do a empirical research because of the insufficiency of the existing data, so this paper issued all the data analysis of commercial bank loan loss provisions, which has played an important role in exploring the deposit insurance system in the development of China's banking industry . 


\section{Hypotheses}

\subsection{The Influence of Deposit Insurance System for Loan Loss Provisions}

The role of the provision for loan loss provisions mainly has two points: first, capital buffers. Commercial banks from the current operating profit in the provision of a certain loss reserves, when actual offset against impairment loss, avoid the erosion of bank capital, prevent due to the volatility of bank earnings triggered a banking crisis. Second, give a warning about loan risk. Commercial banks often take assessment on loan loss provisions, then they will adjustment their value, which play an important role on defending crises. Under the original implicit insurance system, all of the financial crisis in the bank shall be borne by the government, with insurance system from the recessive to dominant, the country no longer bear the bank losses in full, but the parts. Under the background of the system, the bank will be out of concern that the loan is difficult to recycle or unable to recycle the motives of huge capital losses caused choice provision more loan loss provisions, for a rainy day.

Under the implicit insurance system, set up by the ministry of finance of the acquisition, management and disposal of financial asset management companies objects are large commercial banks, the original implicit insurance system under the concept of "too big to fail" make depositors tend to choose high degree of protection of the state-owned banks, leads to the five big state-owned banks in China banking market structure of monopoly, the development of small and medium-sized bank limited [16]. But with the implementation of the deposit insurance system, the bigger banks will take more measures than smaller banks because they will not have the special protections from government any more. On this basis, this paper presents the first assumption:

H1: Following the promulgation of the deposit insurance system, loan loss provisions increased, besides, the greater bank affected by the system to increase loan loss provisions phenomenon is more obvious.

\subsection{Deposit Insurance System and the Manipulated Loan Loss Provisions}

Loan loss provisions is different from general accountant course, it is the banks themselves based on the analysis of the loan loss provision, judgment and estimation, inevitably there is biggish subjectivity on the provision. From previous research of scholars both at home and abroad, the influencing factors of bank loan loss provisions plan consists of discretionary and non discretionary factors. Among them, the discretionary factors mainly include bank cannot control the size of the loans (LOAN), non-performing loans (NPL) and net charge-offs bad debts (NCO), another part of the loan loss provisions as banks are discretionary part [17]. Dominant system, issued by banks from the Angle of risk prevention, management will actively increase the playable part of your loan loss provisions, use to prevent the debt crisis. On the basis of which the second hypothesis of 
text:

$\mathrm{H} 2$ : Issued after the deposit insurance system, the bank added the control part of the loan loss provisions.

\subsection{Deposit Insurance System and the Motive of Income Smoothing}

Loan loss provisions are a reflection of the principle of caution accounting, its purpose is to enhance the bank risk prevention ability, promote the stable operation of commercial bank. If commercial banks' loan loss provisions were bigger, the lower individual risk and spillover risk would be. The behavior of income smoothing weakens the defense capabilities of loan loss provisions. If commercial banks are influenced by the behavior and fails to extraction and preparation, the individual risk and the spillover risk would be higher than before [18]. Following the promulgation of the deposit insurance system, as banks need to take the risk of more and more high, so in order to enhance their risk coping ability, smooth behavior will reduce profit, to alleviate pressure caused by system promulgated by the new. Deposit insurance system in our country, on the other hand, set the highest pay limitation of 500,000 covers $99.63 \%$ of the depositors in China, the depositors deposit is basic get effective guarantee. Based on this, the depositor is more of a turn on bank deposit rates. If the bank to raise the interest rates on deposits, it needs a high income, and yield of the reaction on its profits. A lucrative as a result, banks will not choose the behavior of income smoothing any more, instead, they hope depositors and investors deliver a good news through high profits. Let them have a good attitude for the banks, which attract a large number of depositors deposit. On the basis of this paper proposed a third hypothesis:

H3: Following the promulgation of the deposit insurance system, banks decrease the motivation of income smoothing by using loan loss provisions.

\section{Sample Selection and Empirical Models}

This article selects 2012-2017 from Bankscope database of all the relevant data of commercial banks in our country. To be sure, although the deposit insurance system in our country is formally promulgated on May 1, 2015, but in early November 27, 2014, the legal office of the state council has released the full "deposit insurance regulations (draft)". So in this paper, with the promulgation of the deposit insurance system in 2015 as a cut-off point, compared before and after bank loan loss provisions system promulgated provisions.

To verify the hypothesis, this paper as follows: (1) model is established, including system promulgated Sys as dummy variables, year 1 , otherwise 0 . If $a_{1}$ is greater than zero, suggests that our country's loan provision provision is increased after the promulgation of the deposit insurance system. Previous research used non-performing loans (NPL) and the size of the LOAN (LOAN) to measure loan loss provisions of discretionary factors. Non-performing loan ratio is higher, 
the more the bank for the provision of loan loss provisions, therefore, in this paper, we control the non-performing loan ratio. In addition, if a bank's LOAN too fast, the risk of loss will increase, so this paper will be control LOAN scale (LOAN). Model (1) the control variable did not add bank SIZE (SIZE) and core capital adequacy ratio (Tier1), because the two variables is more influence the playable loan loss provisions part, not affect the normal loan loss provisions plan the general factors [2] [19].

$$
\begin{aligned}
\mathrm{LLP}= & a_{0}+a_{1} \mathrm{Sys}+a_{2} \mathrm{NPL}+a_{3} \mathrm{LO} A \mathrm{~N}+a_{4} \mathrm{EBTP} \\
& +a_{5} \mathrm{GROWTH}+a_{6} \mathrm{NCO}+a_{7} \mathrm{ROE}+\varepsilon
\end{aligned}
$$

To verify the hypothesis two, this article used model in the existing literature on manageable loans to separate provisions [17], a two-stage regression method is used to extract the playable loan loss provisions. First of all, as shown in the following model (2) the factors affecting the loan loss provisions cannot control, namely the non-performing loans (NPL), the size of the LOAN (LOAN) and net write-offs (NCO) to return, the residual is manageable loans.

$\mathrm{LLP}=\alpha_{0}+\alpha_{1} \mathrm{NPL}+\alpha_{2} \Delta \mathrm{NPL}+\alpha_{3} \mathrm{LOAN}+\alpha_{4} \Delta \mathrm{LOAN}+\alpha_{5} \mathrm{NCO}+\varepsilon$

The second step, the above model is the residual as explained variable, into the model as shown below. In order to analyze the management is to achieve a specific purpose, based on the model in the core capital adequacy ratio (Tier1), provisions before pre-tax profits (EBTP) for managers of capital management and profit smooth motivation for analysis. From the point of profit smooth motivation, commercial banks will choose in profitable years overvalued loan loss provisions, low profit year underestimate loan loss provisions. It seems that provisions before pre-tax profits high and low will affect the management of provisions of the loan loss provisions manipulation, therefore in the model to set aside pre-tax profits before (EBTP) control. In addition to the core capital adequacy ratio (Tier1) as control variable, the reason is that the core capital adequacy ratio to tier 1 capital of banks' capital, it did not include provisions into the attached capital loans, so the core capital adequacy ratio is adopted to study capital management motivation has more explanatory power.

DLLP $=\beta_{0}+\beta_{1}$ Sys $+\beta_{2}$ EBTP $+\beta_{3}$ SIZE $+\beta_{4}$ Tier $1+\beta_{5}$ GROWTH $+\varepsilon$

To verify the hypothesis 3 , as shown in the following model (4) in this paper. To explore issued on bank deposit insurance system of loan loss provisions profit smooth the impact of motivation, in this paper, on the basis of the benchmark model, the introduction of deposit insurance system and provisions for former pre-tax profit by item. If significant negative abnormal $c_{3}$, verify the hypothesis three, following the promulgation of the deposit insurance system, banks used to make a profit motive of smooth loan loss provisions. In addition, because of the different characteristics of bank will have different effect on bank business decisions, and thus affect the provision for loan loss provisions management, we can choose bank SIZE (SIZE), return on equity (ROE), asset GROWTH rate (GROWTH) to control the bank basic information. 


$$
\begin{aligned}
\mathrm{LLP}= & c_{0}+c_{1} \text { EBTP }+c_{2} \text { Sys }+c_{3} \text { EBTP } \times \text { Sys }+c_{4} \mathrm{NPL}+c_{5} \text { LOAN } \\
& +c_{6} \mathrm{NCO}+c_{7} \text { GROWTH }+c_{8} \text { ROE }+c_{9} \text { Tier } 1+c_{10} \text { SIZE }+\varepsilon
\end{aligned}
$$

\section{The Empirical Results}

\subsection{Descriptive Statistics}

To protect against the effects of extreme value, in this paper, all the data are processed for fore and aft $1 \% \mathrm{Mr}$ Winsor, main variables of descriptive statistics as shown in the above (Table $1 \&$ Table 2). After deleting the missing variables, we got 813 efficient unbalanced data finally. The statistical result can be seen from Table 2, we find that the average of our country commercial bank loan loss provisions is $1.34 \%$. In addition, the minimum of capital adequacy is $7.74 \%$, the average is $14.08 \%$, which shows that our commercial bank capital adequacy ratio reached the requirem ents of the Basel $\mathbb{I I} 8 \%$. The average of non-performing loan ratio (NPL) was $1.50 \%$, which was closer to $2 \%$ of the red line, it can be seen that Chinese commercial banks are still having many bad loans.

\subsection{Regression Results}

Respectively in this paper, to make sure if the data is fitted for the return of the random effects model or fixed effect model, after checked by Hausman, finally by using the fixed effects model. By the way, all the regression results are used robustness test. Regression analysis on results can be seen from Table 3, Sys coefficient significantly positive and show that bank loans provision set aside increased significantly after promulgated in the deposit insurance system, namely the bank really influenced by the regulatory policy, take a risk to take certain measures. Again next, this article according to the division of bank assets, take on the total assets of logarithmic one-third of the bank for big banks, under a third of small banks, to set up a new dummy variable S, S one for big banks, namely otherwise for small banks. Next, we carry out regression analysis on

Table 1. Variable definition.

\begin{tabular}{cl}
\hline Variable name & \\
\hline LLP & Loan loss provisions (LLPs) scaled by beginning total assets \\
Sys & Indicator variable set equal to 1 if system issued, and 0 otherwise \\
EBTP & Earnings before provisions and taxes scaled by beginning total assets \\
Tier1 & Tier 1 is the ratio of Tier 1 capital to risk weighted assets \\
NPL & Beginning non-performing scaled by beginning total assets \\
LOAN & Beginning total loans outstanding scaled by beginning total assets \\
NCO & Net charge-offs scaled by beginning total assets \\
GROWTH & Growth in total assets from the beginning to the end of year $\mathrm{t}$ \\
ROE & Beginning net income scaled by beginning net assets \\
SIZE & Natural logarithm of beginning total assets \\
S & Indicator variable set equal to 1 if bank is a biger one, and 0 otherwise \\
\hline
\end{tabular}


Table 2. Descriptive statistics.

\begin{tabular}{ccccccc}
\hline Variable & $\mathrm{N}$ & Mean & Standard error & First quantile & Median & Third quantile \\
\hline LLP & 813 & 0.0134 & 0.0080 & 0.0001 & 0.0123 & 0.0459 \\
NPL & 813 & 0.0150 & 0.0094 & 0.0005 & 0.0140 & 0.0643 \\
LOAN & 813 & 0.4143 & 0.1696 & 0.0061 & 0.4250 & 0.9382 \\
Tier1 & 813 & 14.0763 & 12.8696 & 7.7400 & 10.9700 & 110.9200 \\
NCO & 813 & 0.0011 & 0.0174 & -0.4362 & 0.0012 & 0.1144 \\
GROWTH & 813 & 20.4231 & 22.8277 & -17.0100 & 15.6700 & 130.6300 \\
ROE & 813 & 12.4638 & 6.6274 & 0.0000 & 12.5450 & 76.6900 \\
SIZE & 813 & 18.4632 & 1.8904 & 12.5074 & 18.4493 & 24.2605 \\
EBTP & 813 & 0.0167 & 0.0028 & 0.0140 & 0.0164 & 0.0349 \\
\hline
\end{tabular}

Table 3. Estimation of all LLPs.

\begin{tabular}{cccc}
\hline & LLP & $\operatorname{LLP}(\mathrm{S}=1)$ & $\operatorname{LLP}(\mathrm{S}=0)$ \\
\hline Sys & $0.0012^{* * *}(3.68)$ & $0.0015^{* * *}(4.19)$ & $0.0015(1.06)$ \\
NPL & $0.1005^{* * *}(5.84)$ & $0.0819^{* * *}(3.34)$ & $0.0599(1.36)$ \\
LOAN & $0.0237^{* * *}(9.10)$ & $0.0216^{* * *}(7.46)$ & $0.0351^{* * *}(3.21)$ \\
NCO & $-0.8819^{* *}(-2.02)$ & $-0.0001^{*}(-1.83)$ & $-0.0166(-1.55)$ \\
EBTP & $0.2234^{* *}(2.12)$ & $0.2534^{* *}(2.23)$ & $0.4906(1.07)$ \\
GROWTH & $-0.0000^{* * *}(-4.01)$ & $-0.0000^{* * *}(-2.82)$ & $-0.000(-1.39)$ \\
ROE & $-0.0001^{*}(-1.80)$ & $-0.000(-0.27)$ & $-0.0002(-1.13)$ \\
cons & $-0.0009(-0.45)$ & $-0.0022(-0.92)$ & $-0.0067(-0.75)$ \\
Annual fixed effect & yes & yes & yes \\
$\mathrm{N}$ & 574 & 310 & 89 \\
$\mathrm{R}^{2}$ & 0.39 & 0.40 & 0.47 \\
\hline
\end{tabular}

Note: ${ }^{*} \mathrm{p}<0.1,{ }^{* *} \mathrm{p}<0.05,{ }^{* * *} \mathrm{p}<0.01$.

these two sets of data respectively. From the result as you can see, the big banks in the system following the promulgation of provisions for loan increased significantly, but the small bank deposit insurance system and loan loss provisions and no significant correlation, the promulgation of the deposit insurance system to the influence of the big banks is more apparent, verify the hypothesis.

The results of regression model (2) as shown in Table 4. The on the model (2) regression residuals is the banks can control part of the loan. Extracted from model (2) the residuals of the results found that can control the loan loss provisions are all positive, shows that our country banking industry mainly based on the prudence principle as the guidance, the use of loan provisions for profit smooth performance good mainly for the year, and there are no performance difference of contributions for less. We add the regression residuals on the model (2) into model (3), the results of regression model (3) as shown in Table 4. From the table as you can see, the deposit insurance system (Sys) coefficient is significantly positive, which verify the hypothesis two, after issued by commercial 
Table 4. Estimation of DLLPs.

\begin{tabular}{|c|c|c|}
\hline & LLP & DLLP \\
\hline NPL & $0.1559^{\star * *}(9.07)$ & \\
\hline$\triangle \mathrm{NPL}$ & $0.0000(-0.26)$ & \\
\hline LOAN & $0.0254^{\star * *}(9.50)$ & \\
\hline$\triangle \mathrm{LOAN}$ & $0.0000(0.07)$ & \\
\hline NCO & $-0.0000(-0.51)$ & \\
\hline Sys & & $0.0004^{\star \star}(2.28)$ \\
\hline EBTP & & $0.0881(1.13)$ \\
\hline SIZE & & $-0.0021^{\star \star \star}(-4.42)$ \\
\hline Tier1 & & $0.0000(-0.59)$ \\
\hline GROWTH & & $-0.0001^{\star * *}(-9.44)$ \\
\hline$c$ & $0.0003(0.23)$ & $0.0548^{\star * *}(5.39)$ \\
\hline Annual fixed effect & yes & yes \\
\hline $\mathrm{N}$ & 598 & 476 \\
\hline $\mathrm{R}^{2}$ & 0.32 & 0.31 \\
\hline
\end{tabular}

banks in deposit insurance system, increase is manageable portion of the loan provision for provision.

This paper, by using model (4) test whether bank profits by loan loss provisions smooth motivation abate or not, regression results as shown in Table 5. We can found that deposit insurance system and pre-tax profit before provisions by a significantly negative, illustrate the promulgation of the deposit insurance system indeed suppresses the bank using loan loss provisions for income smoothing, so as to verify the hypothesis three. By comparing the various regression results, we found that the bank is in the deposit insurance system following the promulgation of increased provision of loan provisions, but not for profit motive of smooth, regression results that the bank is out of risk prevention, the influence of system increases the loan loss provisions, not out of reach a certain purpose and increase the provisions of the loan. In addition, we use model (4) for grouping size banks after the handover, found that assumes that the same data the results are the same, the big banks used to make a profit motive of smooth loan loss provisions, small profits smooth motivation to change is not obvious. Visible, the implicit insurance system of shelter under the risk response measures taken by the big banks more apparent, small banks in front of the dominant system of insurance issued has been largely out of state for themselves, so the profit smooth motives are not under the influence of the system is too big.

\section{Robustness Test}

\subsection{Alternative Analysis of Bank Size}

In research of existing in our country, the size of banks there are many types of 
Table 5. Impact of deposit insurance system on income smoothing.

\begin{tabular}{cccc}
\hline & LLP & LLP $(S=1)$ & LLP $(S=0)$ \\
\hline EBTP & $0.4506^{* * *}(3.45)$ & $0.7504^{* * *}(6.16)$ & $68(1.10)$ \\
Sys*EBTP & $-0.1578^{* * *}(-3.10)$ & $-0.1559^{* * *}(-3.59)$ & $-69.97(-1.13)$ \\
Sys & $0.0041^{* * *}(4.02)$ & $0.0040^{* * *}(4.30)$ & $1.229(1.13)$ \\
NCO & $-0.031(-0.61)$ & $-0.0138(-0.23)$ & $0.124(0.69)$ \\
NPL & $0.1445^{* * *}(5.56)$ & $0.1186^{* * *}(3.24)$ & $0.3614^{* * *}(3.46)$ \\
LOAN & $0.0250^{* * *}(9.13)$ & $0.0246^{* * *}(8.16)$ & $0.0378^{* * *}(3.31)$ \\
GROWTH & $-0.0000^{* * *}(-3.69)$ & $-0.0000^{* *}(-2.05)$ & $0.0001^{*}(1.86)$ \\
ROE & $0.0000(-0.47)$ & $0.0000(0.19)$ & $0.0003^{*}(1.96)$ \\
SIZE & $0.0006(0.89)$ & $0.0032^{* * *}(4.36)$ & $-0.0168^{* * *}(-3.25)$ \\
Tier1 & $0.0001^{* * *}(3.39)$ & $0.0003^{* *}(2.35)$ & $0.0001(0.39)$ \\
$c$ & $-0.0214(-1.33)$ & $-0.0816^{* * *}(-4.83)$ & $-0.922(-0.82)$ \\
Annual fixed effect & yes & yes & yes \\
N & 513 & 290 & 69 \\
$\mathrm{R}^{2}$ & 0.49 & 0.53 & 0.81 \\
\hline
\end{tabular}

proxy variables, such as loan scale, the scale of bad loans and assets [20]. In assuming a test, this paper uses the size of the assets to measure the scale of banks, then with the size of the LOAN (LOAN) to distinguish the size of the bank as the proxy variable to test again. In one model is introduced into the size of the LOAN (LOAN) and deposit insurance system (Sys) by again after the item, the regression results as you can see, the size of the LOAN and deposit insurance system by coefficient is positive, that following the promulgation of the deposit insurance system, the bigger banks, the LOAN provision for more provisions. Thus, whether measured by assets or the size of the loan bank, the size of the conclusions are consistent, the bigger banks and affected by the deposit insurance system and increase the number of loan loss provisions more, this conclusion is also in line with expectations, system promulgated before the national key support object is a large commercial banks, these banks after the deposit insurance system promulgated, "too big to fail" no longer, only by giving more before loan provisions against risks by the state (Table 6).

\subsection{Whether Banks Have Other Replacement Effects to Compensate for the Reduced Profits Smooth Motives}

Although after the empirical analysis found that the bank through the loan loss provisions weakened profit motive of smooth, but the bank's profit smooth motivation is really weakened, or through other substitution effect, it is need to do further inspection. Bank to use discretionary loan loss provisions, mainly from profit smooth motive, capital management, motivation and signal transfer motivation, here in this paper, the capital management motivation for further study, to test the promulgation of the deposit insurance system's impact on banks' capital management motivation. Empirically found that either system before and after 
Table 6. Alternative analysis of bank size.

\begin{tabular}{cc}
\hline Sys & LLP \\
\hline LOAN $\times$ Sys & $-0.00110(-1.14)$ \\
NPL & $0.0051^{* *}(2.51)$ \\
LOAN & $0.0987^{* * *}(5.77)$ \\
NCO & $0.0213^{* * *}(7.71)$ \\
EBTP & $-1.1251^{* *}(-2.53)$ \\
GROWTH & $0.1874^{*}(1.78)$ \\
ROE & $-0.0000^{* * *}(-3.50)$ \\
$c$ & $-0.0001^{*}(-1.91)$ \\
Annual fixed effect & $0.0009(0.41)$ \\
$\mathrm{N}$ & yes \\
$\mathrm{R}^{2}$ & 574 \\
\hline
\end{tabular}

Table 7. Impact of deposit insurance system on capital management.

\begin{tabular}{cc}
\hline Sys & LLP \\
Tier1 & $0.0030^{* * *}(6.51)$ \\
Tier1 $\times$ Sys & $0.0000(0.54)$ \\
NPL & $-0.0001^{* * *}(-4.08)$ \\
LOAN & $0.1534^{* * *}(8.70)$ \\
NCO & $0.0277^{* * *}(12.99)$ \\
EBTP & $-0.8625^{* * *}(-2.66)$ \\
ROE & $0.1784^{* *}(2.17)$ \\
SIZE & $0.0000(0.87)$ \\
GROWTH & $-0.0006^{* *}(-2.54)$ \\
$c$ & $-0.0000^{* * *}(-3.31)$ \\
Annual fixed effect & $0.0061(1.37)$ \\
$\mathrm{N}$ & yes \\
$\mathrm{R}^{2}$ & 515 \\
\hline
\end{tabular}

promulgated, core capital adequacy ratio is negatively related to the loan provision for all the time, and did not differ significantly between coefficient. (4), using the same model with the core capital adequacy ratio (Tier1) as explained variable, the original item into the core capital adequacy ratio and paying the deposit insurance system of the passenger. Regression found that take a significant negative coefficient, show that following the promulgation of the deposit insurance system, the motive of bank capital by loan loss provisions management not only is restrained, it enhances the motivation, visible bank in order to attract a large number of investors, may use capital boost its capital adequacy ratio management behavior, in order to obtain investors or depositors' confidence (Table 7). 


\section{Conclusion}

This paper mainly researched the impact of the promulgation of the deposit insurance system. We tested whether the system could weaken the motive of income smoothing by using loan loss provisions. The transition from the implicit system to the explicit deposit insurance system leaded all commercial banks, especially those large commercial banks increasing loan loss provisions because of awareness of risk prevention. In addition, the motive of income smoothing in banks has also been weakened after the promulgation of the deposit insurance system because of the same awareness of risk prevention. We can find that there would be a truer and fair trading environment not only for investors, but also protecting the interests of sporadic retail depositors. At the same time, the research conclusion of this paper shows that the bank's capital management motivation can be increased. It is the substitution effect of bank profits' smooth motivation, or due to other reasons, is a topic worth continuing to explore.

\section{Conflicts of Interest}

The author declares no conflicts of interest regarding the publication of this paper.

\section{References}

[1] Pan, G.F. (2017) Research on Deposit Insurance System of Chinese Model. Times Finance, No. 8, 242-248.

[2] Ahmed, A.S., Takeda, C. and Thomas, S. (1999) Bank Loan Loss Provisions: A Reexamination of Capital Management, Earnings Management and Signaling Effects. SSRN Electronic Journal, 28, 1-25.

[3] Morgan, D.P. (2000) Rating Banks: Risk and Uncertainty in an Opaque Industry. American Economic Review, 92, 874-888. https://doi.org/10.1257/00028280260344506

[4] Beatty, A., Chamberlain, S.L. and Magliolo, J. (1995) Managing Financial Reports of Commercial Banks: The Influence of Taxes, Regulatory Capital, and Earnings. Journal of Accounting Research, 33, 231-261. https://doi.org/10.2307/2491487

[5] Liu, C.C. and Ryan, S.G. (1995) The Effect of Bank Loan Portfolio Composition on the Market Reaction to and Anticipation of Loan Loss Provisions. Journal of Accounting Research, 33, 77. https://doi.org/10.2307/2491293

[6] Kanagaretnam, K., Lobo, G.J. and Mathieu, R. (2003) Managerial Incentives for Income Smoothing through Bank Loan Loss Provisions. Review of Quantitative Finance and Accounting, 20, 63-80. https://doi.org/10.1023/A:1022187622780

[7] Moyen, S. (1990) Capital Adequacy Ratio Regulations and Accounting Choices in Commercial Banks. Journal of Accounting \& Economics, 2, 123-154.

[8] Kim, M.S. and Kross, W. (1998) The Impact of the 1989 Change in Bank Capital Standards on Loan Loss Provisions and Loan Write-Offs. Journal of Accounting and Economics, 25, 69-99. https://doi.org/10.1016/S0165-4101(98)00015-9

[9] Ding, Y.G., Wang, B.B. and Li, Y.M. (2018) Provision for Bank Loans: A Literature Review. Financial Research, No. 1, 86-94.

[10] Suning (2005) Learn from International Experience and Accelerate the Establish- 
ment of Deposit Insurance System Suitable for China's National Conditions. Research on Finance Investigate, No. 12, 1-5.

[11] Li, Y. and Han, L. (2008) Franchise Value, Implicit Insurance and Risk Taking-Experience of Chinese Banking Industry Analysis. Financial Research, No. 1, 76-87.

[12] Yan, H. (2004) Difficulties and Choices Faced by China in Establishing Deposit Insurance System. Financial Research, No. 11, 29-36.

[13] Gropp, R. and Vesala, J. (2004) Deposit Insurance, Moral Hazard and Market Monitoring. Review of Finance, 8, 571-602. https://doi.org/10.1093/rof/8.4.571

[14] Yao, D., Yan, J. and Yin, Y. (2013) Deposit Insurance System or the Central Bank Directly to Save the Market?-A Dynamic Game. Economic Research, No. 10, 43-54.

[15] Zhang, J. and Sun, Y. (2016) Empirical Study on the Impact of Deposit Insurance System on Bank Risk Bearing. Economics and Finance Management, No. 1, 36-45.

[16] Song, L. (2015) Research on the Impact of Deposit Insurance System on Small and Medium-Sized Commercial Banks and Countermeasures. Macroeconomic Research Investigate, No. 11, 84-92.

[17] Kanagaretnam, K., Lobo, G.J. and Yang, D.H. (2004) Joint Tests of Signaling and Income Smoothing through Bank Loan Loss Provisions. Contemporary Accounting Research, 21, 843-884. https://doi.org/10.1506/UDWQ-R7B1-A684-9ECR

[18] Dai, D. and Zhang, S. (2016) Loan Loss Preparation, Earnings Management and Risk Control of Commercial Banks. Accounting Research, No. 8, 25-33.

[19] Fonseca, A.R. and Gonzalez, F. (2008) Cross-Country Determinants of Bank Income Smoothing by Managing Loan-Loss Provisions. Journal of Banking \& Finance, 32, 217-228. https://doi.org/10.1016/j.jbankfin.2007.02.012

[20] Wang, X. (2010) Empirical Research on Bank Loan Loss Reserve. China Management Informatization, No. 8, 53-55. 